\title{
Involvement of cell cycle progression in survival signaling through CD40 in the B-lymphocyte line WEHI-231
}

\author{
H Hirai $^{1}$, T Adachi $^{1}$ and T Tsubata ${ }^{*, 1}$ \\ ${ }^{1}$ Laboratory of Immunology, School of Biomedical Science, and Department of \\ Immunology, Medical Research Institute, Tokyo Medical and Dental University, \\ Tokyo, Japan \\ * Corresponding author: T Tsubata, Laboratory of Immunology, School of \\ Biomedical Science, and Department of Immunology, Medical Research \\ Institute, Tokyo Medical and Dental University, 1-5-45 Yushima, Bunkyo-ku, \\ Tokyo 113-8510, Japan. Tel: + 8135803 5817; Fax: + 8135684 0717; \\ E-mail: tsubata.imm@mri.tmd.ac.jp
}

Received 17.3.03; revised 06.8.03; accepted 21.8.03; published online 28.11.03 Edited by $\mathrm{H}$ Ichijo

\section{Abstract}

The CD40 molecule transmits a signal that abrogates apoptosis induced by ligation of the antigen receptor (BCR) in both primary B cells and B-cell lines such as WEHI-231. Expression of $B c l-x L$ and $A 1$, antiapoptotic members of the $\mathrm{Bcl}-2$ family, is enhanced by CD40 ligation, and is suggested to mediate CD40-induced B-cell survival. CD40 ligation also promotes cell cycle progression by increasing the levels of cyclin-dependent kinases (CDKs) required for cell cycle progression, and reducing expression of the CDK inhibitor

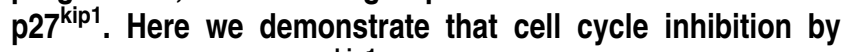
retrovirus-mediated $\mathrm{p} 2 \mathrm{k}^{\mathrm{kip} 1}$ expression does not modulate the levels of $B c l-x L$ or $A 1$, but significantly reduces the survival of BCR-ligated WEHI-231 cells by CD40 ligation. This indicates that cell cycle progression is crucial for CD40-mediated survival of $B$ cells.

Cell Death and Differentiation (2004) 11, 261-269. doi:10.1038/ sj.cdd. 4401357

Published online 28 November 2003

Keywords: apoptosis; B lymphocyte; cell cycle progression; CD40; Bcl-xL; A1; p27 kip1 $^{\text {kip }}$

Abbreviations: $B C R$, B-cell antigen receptor; $C D K$, cyclindependent kinase; $A b$, antibody; $\mathrm{mAb}$, monoclonal antibody; PE, phycoerythrin; BrdU, 5-bromo-2'-deoxyuridine; FITC, fluorescein isothiocyanate; $\mathrm{PI}$, propidium iodide

\section{Introduction}

CD40 is a member of the TNF receptor family expressed on immune cells such as B lymphocytes (B cells), macrophages and dendritic cells, and plays a crucial role in both humoral and cellular immune responses. ${ }^{1,2} \mathrm{CD} 40$ transmits a survival signal at least in B cells. CD40 ligation delays the apoptosis of normal $\mathrm{B}$ cells cultured in vitro with medium alone, demonstrating that CD40 transmits a signal that inhibits 'sponta- neous apoptosis' of B cells. CD40 ligation also blocks the apoptosis induced by ligation of the B-cell antigen receptor (BCR) in both normal B cells and B-cell lines such as WEHI$231 .^{3-5} \mathrm{BCR}$-ligated $B$ cells survive in the presence of CD40 ligation, thereby participating in humoral immune responses. CD40L, the ligand for CD40, is a member of the TNF family expressed on activated $T$ cells as a membrane protein. ${ }^{1}$ Antigen-stimulated $\mathrm{B}$ cells thus require interaction with CD40L-expressing T-helper cells for survival and activation. Self-reactive B cells are suggested to be unable to achieve this requirement and to undergo apoptosis, resulting in maintenance of self-tolerance. ${ }^{3,6}$

Two distinct pathways are involved in the induction of apoptosis. ${ }^{7-9}$ The extrinsic pathway is activated by death receptors, which form a complex with caspases essential for apoptosis, and activate them upon interaction with the ligands. The other pathway called the intrinsic pathway or mitochondrial pathway involves mitochondrial dysfunction, which causes release of cytochrome $c$ from the mitochondria. The released cytochrome $c$ then activates caspase 9 by forming a complex termed apoptosome with Apaf-1 and caspase 9 . Members of the $\mathrm{Bcl}-2$ family regulate this pathway. Proapoptotic members of this family such as Bax and Bak induce mitochondrial dysfunction, whereas mitochondria is protected by antiapoptotic members of the Bcl-2 family such as $\mathrm{Bcl}-2$ and $\mathrm{Bcl}-\mathrm{xL}$. CD40 ligation blocks B-cell apoptosis most likely by protecting mitochondria, as it abrogates mitochondrial dysfunction such as mitochondrial membrane potential transition and cytochrome $c$ release induced by BCR ligation. ${ }^{10,11} \mathrm{CD} 40$-mediated protection of mitochondria appears to involve antiapoptotic members of the Bcl-2 family Bcl$x \mathrm{~L}$ and $\mathrm{A} 1$. Indeed, expression of these molecules is induced by CD40 ligation, and their overexpression protects $B$ cells from BCR ligation-induced apoptosis. ${ }^{12-17}$ These antiapoptotic members of the Bcl-2 family may thus mediate the survival of BCR-ligated B cells induced by CD40 signaling, through abrogation of mitochondrial dysfunction.

Although CD40 ligation alone induces proliferation of $B$ cells only marginally, ${ }^{1,18} \mathrm{CD} 40$ signaling appears to activate the signaling pathways required for proliferation. Resting primary $B$ cells express a high level of the cyclin-dependent kinase (CDK) inhibitor $\mathrm{p} 27^{\mathrm{kip} 1}$, which blocks cell cycle progression by inhibiting the CDK activity essential for cell cycle progression, ${ }^{19}$ and CD40 signaling alone reduces $p 27^{\text {kip }}{ }^{1}$ almost completely in these cells. ${ }^{20} \mathrm{CD} 40$ ligation induces increase in the levels of CDK2 and CDK4, ${ }^{15,20}$ as well as reduction of p27 $7^{\text {kip1 }}$ in BCR-ligated WEHI-231 cells. These findings indicate that CD40 signaling induces molecular events involved in cell cycle progression. This is also supported by the finding that $\mathrm{CD} 40$ ligation induces proliferation as well as survival of BCR-ligated WEHI-231 cells, ${ }^{3}$ which otherwise undergo cell cycle arrest in the $\mathrm{G} 1$ phase prior to apoptosis. ${ }^{21-24}$ Since overexpression of antiapoptotic 
members of the Bcl-2 family, $\mathrm{Bcl}-\mathrm{xL}$ and $\mathrm{A} 1$, blocks apoptosis but not cell cycle arrest in these cells, ${ }^{15,17}$ survival does not restore the cell cycling of BCR-ligated WEHI-231 cells. Cell cycle progression of BCR-ligated B cells by CD40 ligation thus cannot be attributed to its antiapoptotic activity, but is induced by its cell cycle-promoting function, probably through reduction of $p 27^{\mathrm{kip} 1}$ and induction of CDKs. This observation also indicates that $\mathrm{BCl}-\mathrm{xL}$ and $\mathrm{A} 1$, which are suggested to mediate CD40-induced survival, ${ }^{12-17}$ do not regulate cell cycling. CD40 signaling thus appears to regulate apoptosis and cell cycling by independent signaling pathways.

To assess more closely whether CD40 signaling regulates survival independently of cell cycle progression, we blocked cell cycle progression by retrovirus expression of $p 27^{\mathrm{kip} 1}$ in WEHI-231 cells, and ligated BCR and CD40 on these cells. Although p2 $7^{\mathrm{kip} 1}$-induced cell cycle arrest did not modulate the expression of $\mathrm{Bcl}-\mathrm{xL}$ and A1 by CD40 ligation, CD40mediated survival was markedly reduced. Moreover, the reduced survival was restored by overexpression of $\mathrm{Bcl}-\mathrm{xL}$. These results indicate that the expression levels of endogenous antiapoptotic members of Bcl-2 family are not sufficient for blocking apoptosis by themselves, but require cell cycle progression for the survival of B cells. Our observation strongly suggests a crucial role of cell cycle progression in cell survival.

\section{Results}

\section{Expression of p27 $7^{\mathrm{kip} 1}$ induces cell cycle arrest and partially inhibits CD40-mediated survival of WEHI- 231 cells}

To assess the role of cell cycle progression in CD40-mediated survival of B cells, we infected WEHI-231 cells with retrovirus expressing both $p 27^{\mathrm{kip} 1}$ and GFP, or a control virus expressing GFP alone. After $24 \mathrm{~h}$, we analyzed the expression of GFP by flow cytometry. When we analyzed WEHI-231 cells infected with undiluted virus, almost all the cells expressed

\begin{tabular}{|c|c|}
\hline pMx-IRES-GFP & 5'LTR ${ }^{*}$ IRES GFP 3'LTR \\
\hline pMxKip1-IRES-GFP & 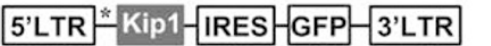 \\
\hline pMxCip1-IRES-GFP & 5'LTR * Cip1-IRES GFP-3'LTR \\
\hline pMxINK4a-IRES-GFP & 5'LTR * INK4a-IRES GFP-3'LTR \\
\hline pMx-IRES-CD 8 & $5^{\prime \prime L T R}{ }^{*}$ IRES CD8 3 3'LTR \\
\hline pMxKip1-IRES-CD8 & 5'LTR * Kip1-IRES CD8 3'LTR \\
\hline pMx-IRES-YFP & 5'LTR * IRES YFP-3'LTR \\
\hline pMxBcl-xL-IRES-YFP & 5'LTR $*$ Bcl-xL-IRES YFP 3'LTR \\
\hline
\end{tabular}

Figure 1 Schematic structures of retroviral vectors. Vectors encoding retrovirus expressing p27 $7^{\mathrm{kip} 1}, \mathrm{p} 16^{\mathrm{INK} 4 \mathrm{a}}, \mathrm{p} 21^{\mathrm{cip} 1}$ or Bcl-xL are schematically represented. These viruses are designed to coexpress GFP, YFP or CD8 for assessing the efficiency of infection. LTR, long-terminal repeat; asterisk, packaging signal; IRES, internal ribosomal entry site; HA, HA-tag
GFP (Figures 1,2a), indicating excellent infection efficiency of these cells. Most of the WEHI-231 cells expressed GFP when cells were infected with virus diluted by two- or three-folds. The fluorescent intensity of GFP-positive cells was almost
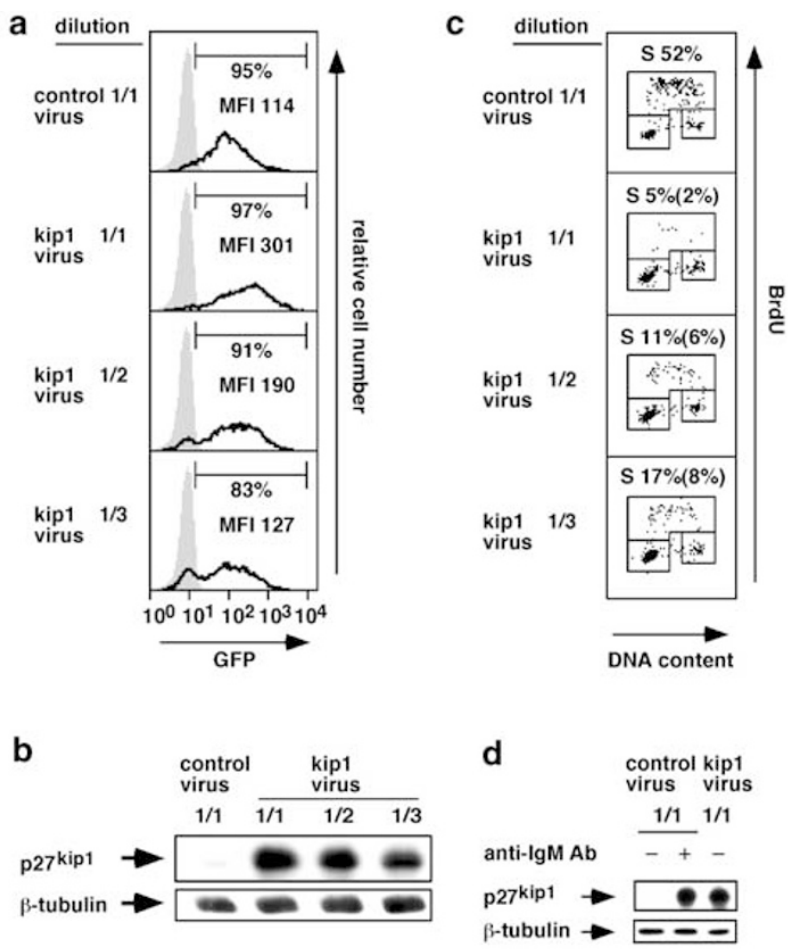

e
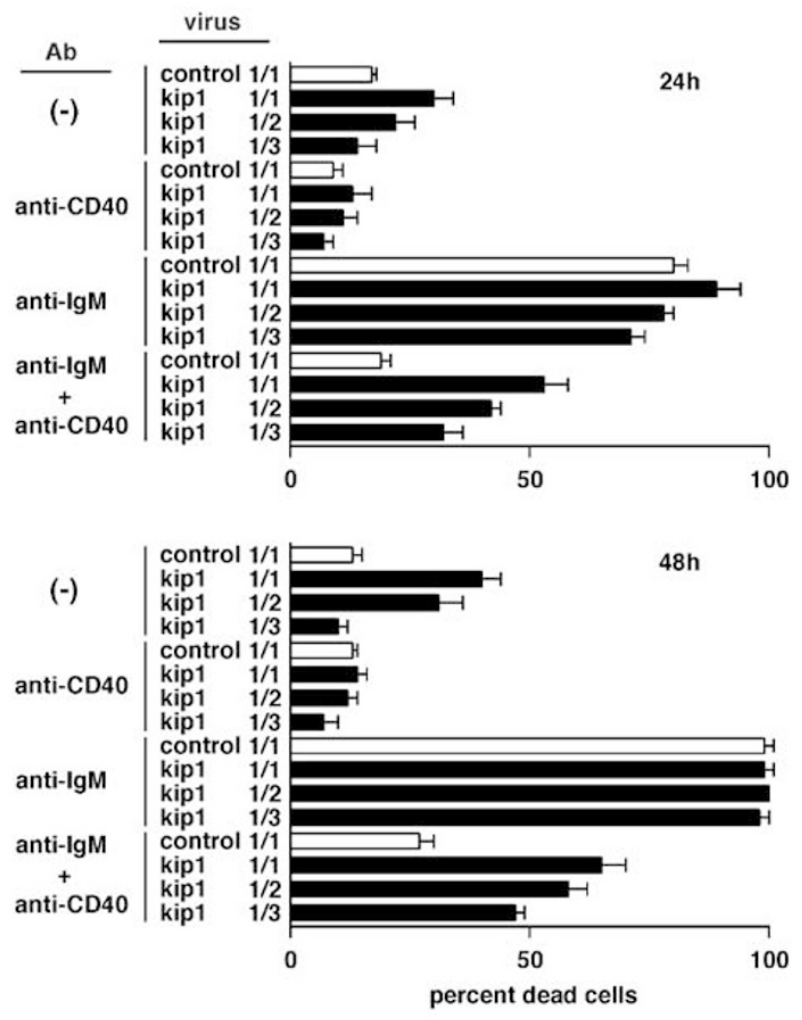
proportional to the virus titer, suggesting that expression of the protein encoded by the virus depends on the titer of virus used for infection. Indeed, expression of p2 $7^{\mathrm{kip} 1}$ protein was proportional to the amount of virus (Figure $2 b$ ). These results indicate that retrovirus infects WEHI-231 cells efficiently, and express p $27^{\text {kip } 1}$ protein whose amount is roughly proportional to the virus titer.

We next compared the expression level of virus-mediated $\mathrm{p} 27^{\mathrm{kip} 1}$ protein to that induced by BCR ligation using anti-IgM antibody $(\mathrm{Ab})$. To avoid the influence of protein degradation associated with BCR-mediated apoptosis, we treated the WEHI-231 Bcl-2 transfectants WEHI-Bcl2 with kip1 virus or anti-IgM Ab, because Bcl-2 expression confers resistance to BCR-mediated apoptosis in WEHI-231 cells. ${ }^{18}$ The level of p2 $7^{\mathrm{kip} 1}$ in WEHI-Bcl2 cells infected with the kip1 virus was similar to that in anti-IgM-treated WEHI-Bcl2 cells (Figure 2d), indicating that virus-mediated expression of p2 $7^{\mathrm{kip} 1}$ is comparable to that induced by BCR ligation in WEHI-231 cells.

Next we assessed whether retrovirus-mediated $\mathrm{p} 27^{\mathrm{kip} 1}$ expression blocks cell cycle progression. When we analyzed the cell cycle status of WEHI-231 cells $24 \mathrm{~h}$ after infection with undiluted kip1 virus, cells in the $S$ phase was almost undetectable, and the fraction of cells in the $\mathrm{G} 1$ phase was increased (Figure 2c), indicating that p2 $7^{\mathrm{kip} 1}$ expression induces almost complete cell cycle arrest in the G1 phase. WEHI-231 cells infected with diluted virus showed marginal increase in the percentage of cells in the $S$ phase compared with those infected with undiluted virus. This increase was not due to increase in the percentage of virus-uninfected cells. Indeed, the percentage of cells in the S phase was increased, though marginally, in virus-infected cells, granted that uninfected cells undergo cell cycle as well as those infected with control virus. These results suggest that infection with kip1 virus induces cell cycle arrest at the G1 phase, in a manner dependent on virus titer.

Figure 2 CD40 signaling rescues WEHI-231 cells from anti-lgM-induced cell death only partially in the presence of $\mathrm{p} 27^{\mathrm{kip} 1}$ expression. The supernatants containing retrovirus expressing both p27 $7^{\mathrm{kip} 1}$ and GFP (kip1 virus) or GFP alone (control virus) were either undiluted (1/1) or diluted by two-fold (1/2) or three-fold (1/3), and were incubated with WEHI-231 (a, b, c and $\mathbf{e}$ ) or WEHI-Bcl2 (d) cells. (a-d) Retrovirus-mediated p27 ${ }^{\text {kip } 1}$ expression. Virus-infected WEHI-231 cells were cultured with medium alone for $24 \mathrm{~h}$. Expression of GFP was analyzed by flow cytometry (a). Percentages of $\mathrm{GFP}^{+}$cells and the mean fluorescence intensities (MFI) of GFP ${ }^{+}$cells are indicated. Expression of $\mathrm{p}^{2} 7^{\mathrm{kip} 1}$ in cell lysates was analyzed by Western blotting using anti-p2 $7^{\mathrm{kip} 1} \mathrm{mAb}(\mathbf{b})$. The same blot was reprobed with anti- $\beta$-tubulin $m A b$ to ensure equal loading. Cells were pulsed with $\mathrm{BrdU}$ at $37^{\circ} \mathrm{C}$ for $20 \mathrm{~min}$, and cell cycle status was analyzed by flow cytometry using anti-BrdU $\mathrm{Ab}$ and PI (c). Percentages of cells in the S phase in kip1 virusinfected cells were calculated. Percentages of cells in the $S$ phase in total cells and in kip1 virus-infected cells (parenthesis) are indicated. The representative data of three experiments are shown. Alternatively, virus-infected WEHI-Bcl2 cells and uninfected WEHI-Bcl2 cells were cultured with or without anti-CD40 Ab, and expression of $\mathrm{p} 27^{\mathrm{kip} 1}$ in cell lysates was analyzed by Western blotting using anti-p2 $7^{\mathrm{kip} 1} \mathrm{mAb}(\mathbf{d})$. The same blot was reprobed with anti- $\beta$-tubulin $\mathrm{mAb}$ to ensure equal loading. (e) Effect of p27 $7^{\mathrm{kip} 1}$ expression on the rescue of BCRligated WEHI-231 cells from apoptosis. WEHI-231 cells were cultured with $10 \mu \mathrm{g} /$ $\mathrm{ml}$ of $\mathrm{F}\left(\mathrm{ab}^{\prime}\right)_{2}$ fragments of goat anti-mouse $\mathrm{lgM} \mathrm{Ab}, 10 \mu \mathrm{g} / \mathrm{ml}$ anti-mouse CD40 mAb HM40-3 or both for $24 \mathrm{~h}$ (upper panel) or $48 \mathrm{~h}$ (lower panel). Viability of the cells was assessed by Trypan blue staining, and percentages of dead cells were calculated. The data represent mean \pm S.D. of triplicate cultures. Representative data of three experiments are shown
To ask whether CD40 signaling blocks BCR-mediated apoptosis in WEHI-231 cells arrested in the G1 phase, we ligated BCR on kip1 virus-infected WEHI-231 cells with anti-Ig $\mathrm{Ab}$ in the presence or absence of agonistic anti-CD40 Ab. In control virus-infected WEHI-231 cells, treatment with anti-Ig Ab killed almost all the cells, but the cells were rescued almost completely by CD40 signaling (Figure $2 \mathrm{e}$ ). Cells infected with kip1 virus died by anti-Ig $A b$ as efficiently as those infected with control virus. Treatment with anti-CD40 Ab reduced the percentage of dead cells in $\mathrm{p} 27^{\mathrm{kip} 1}$-expressing WEHI-231 cells treated with anti-Ig Ab. However, the percentages of dead cells treated with both anti-Ig and anti-CD40 Ab increased dependently on the virus titer, and more than $50 \%$ of the cells were dead in $24 \mathrm{~h}$ in WEHI-231 cells infected with undiluted virus. This result indicated that CD40 signaling rescues anti-Ig-treated WEHI-231 cells only partially in the presence of $\mathrm{p} 27^{\mathrm{kip} 1}$ expression. To ask whether $\mathrm{p} 27^{\mathrm{kip} 1}$ expression enhances apoptosis in WEHI-231 treated with both anti-Ig and anti-CD40 Abs, we measured the percentage of cells containing hypodiploid DNA characteristic for apoptotic cells by flow cytometry (Figure 3 ). In both kip1 virusinfected and control virus-infected cells, most of the cells underwent apoptosis by anti-Ig treatment. Anti-Ig-induced apoptosis was blocked by treatment with anti-CD40 Ab almost completely in control virus-infected WEHI-231 cells. In contrast, the same treatment rescued anti-Ig-induced apoptosis only marginally in kip1 virus-infected WEHI-231 cells.

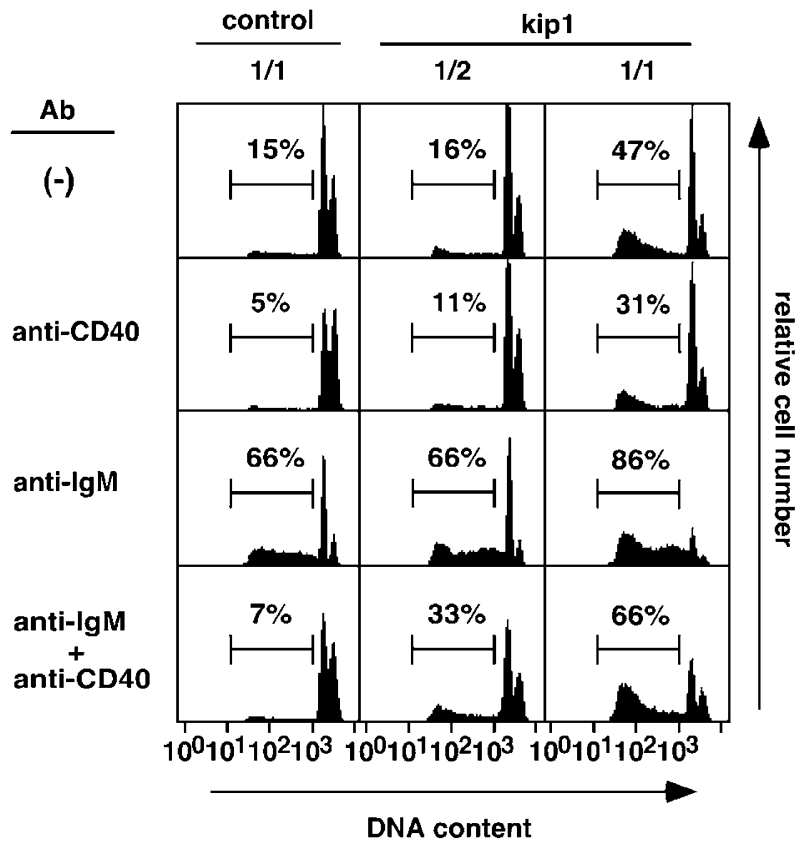

Figure 3 Retrovirus-induced expression of p2 $7^{\text {kip } 1}$ inhibits CD40-mediated survival of BCR-ligated WEHI-231 cells. The supernatants containing retrovirus expressing both p27 ${ }^{\text {kip1 }}$ and GFP (kip1) or GFP alone (control) were either undiluted (1/1) or diluted by two-fold (1/2), and incubated with WEHI-231 cells for $4 \mathrm{~h}$. Cells were then cultured with $10 \mu \mathrm{g} / \mathrm{ml}$ of $\mathrm{F}\left(\mathrm{ab}^{\prime}\right)_{2}$ fragments of goat antimouse IgM Ab, $10 \mu \mathrm{g} / \mathrm{ml}$ anti-mouse CD $40 \mathrm{mAb} \mathrm{HM} 40-3$ or both for $24 \mathrm{~h}$. Cells were fixed, stained with $\mathrm{Pl}$, and analyzed by flow cytometry. Percentages of cells with hypodiploid nuclei are indicated. Representative data of three experiments are shown 
These results indicate that CD40 signaling rescues BCRmediated apoptosis of WEHI-231 cells only partially in the presence of $\mathrm{p} 27^{\mathrm{kip} 1}$ expression. Taken together, p2 $7^{\mathrm{kip} 1}$ expression induces cell cycle arrest in the G1 phase and partially blocks CD40-mediated rescue from apoptosis in BCR-ligated WEHI-231 cells.

\section{Expression of $p 27^{\mathrm{kip} 1}$ does not modulate the expression of A1 or Bcl-xL induced by CD40 signaling}

CD40 signaling induces the expression of antiapoptotic members of the Bcl-2 family Bcl-xL and A1 in B cells, ${ }^{12,14,15,17}$ and these molecules are suggested to play an important role in CD40-mediated survival. We therefore assessed whether the levels of $\mathrm{Bcl}-\mathrm{xL}$ and $\mathrm{A} 1$ are modulated when $\mathrm{p} 27^{\mathrm{kip} 1}$ expression reduces CD40-mediated survival of WEHI-231 cells. Western blotting revealed that expression of $\mathrm{Bcl}-\mathrm{xL}$ and $\mathrm{A} 1$ is induced by treatment with anti-CD40 Ab, and that with both anti-CD40 and anti-Ig Abs, respectively, in control-virus infected WEHI-231 cells (Figure 4). In kip1 virus-infected cells, the expression of $\mathrm{Bcl}-\mathrm{xL}$ and $\mathrm{A} 1$ was induced as efficiently as control virus-infected cells. This result indicated that CD40 signaling blocks BCR-mediated apoptosis only partially in p27 $7^{\mathrm{kip} 1}$-expressing WEHI-231 cells, in spite of their expression of $\mathrm{Bcl}-\mathrm{xL}$ and $\mathrm{A} 1$ similar to control cells. For the complete rescue to BCR-ligated WEHI-231 cells, therefore, expression of $\mathrm{Bcl}-\mathrm{xL}$ and $\mathrm{A} 1$ is not sufficient but cell cycle progression appears to be required.

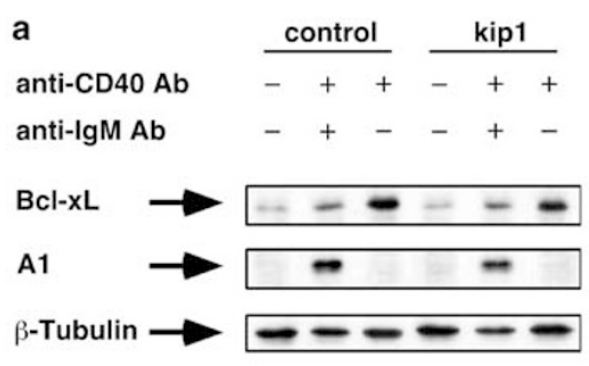

b

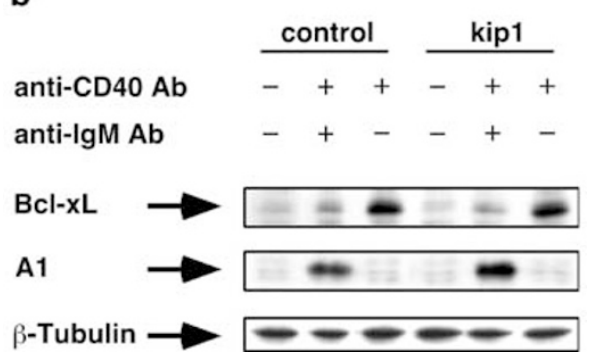

Figure 4 Expression of $p 27^{\mathrm{kip} 1}$ does not modulate the protein levels of $A 1$ and $\mathrm{Bcl}-\mathrm{xL}$ in WEHI 231 cells. WEHI-231 cells were incubated with the supernatants containing retrovirus expressing both p2 $7^{\mathrm{kip} 1}$ and GFP (kip1) or GFP alone (control) for $4 \mathrm{~h}$. Cells were then cultured with $10 \mu \mathrm{g} / \mathrm{ml}$ anti-mouse CD40 mAb HM40-3 in the presence or absence of $10 \mu \mathrm{g} / \mathrm{ml}$ of $\mathrm{F}\left(\mathrm{ab}^{\prime}\right)_{2}$ fragments of goat antimouse IgM Ab for $6 \mathrm{~h}$ (a) or $24 \mathrm{~h}$ (b). Cells were lysed and subjected to Western blot analysis using anti-Bcl-xL Ab (upper panel) and anti-A1 Ab (middle panel). The same blots were reprobed with anti- $\beta$-tubulin $\mathrm{mAb}$ to ensure equal loading (lower panel). Representative data of three experiments are shown
Overexpression of $\mathrm{Bcl}-\mathrm{xL}$ restores the survival of BCR-ligated WEHI-231 cells expressing p27 ${ }^{\mathrm{kip} 1}$

It was previously demonstrated that expression of $\mathrm{Bcl}-\mathrm{xL}$ or A1 blocks BCR ligation-induced apoptosis of WEHI-231 cells almost completely, without inducing cell cycle progression. ${ }^{15,17}$ To resolve the apparent contradiction of this observation with our results, we obtained WEHI-231 cells overexpressing $\mathrm{Bcl}-\mathrm{xL}$ (WEHI-BclxL) using a retrovirus vector. The kip1 virus efficiently infected WEHI-BclxL cells (Figure 5a), and induced cell cycle arrest in the $\mathrm{G} 1$ phase (Figure 5b), as is the case for parent WEHI-231 cells. When we treated kip1 virus-infected WEHI-BclxL cells with anti-Ig $\mathrm{Ab}$ in the presence or absence of anti-CD40 Ab, both cell death and apoptosis were completely blocked, regardless of the presence or absence of anti-CD40 Ab (Figure 5c,d), although $\mathrm{p} 27^{\mathrm{kip} 1}$ expression was comparable to that in kip1 virus-infected WEHI-231 cells (Figure 5e). This result indicates that overexpression of $\mathrm{Bcl}-\mathrm{xL}$ rescues the apoptosis of WEHI-231 cells even in the presence of p27 $7^{\mathrm{kip} 1}$ expression. WEHI-BclxL cells express a much larger amount of $\mathrm{Bcl}-\mathrm{xL}$ than that induced by CD40 ligation (Figure 5f). Thus, $\mathrm{Bcl}-\mathrm{xL}$ is capable of completely blocking BCR-mediated apoptosis, but endogenous $\mathrm{BCl}-\mathrm{xL}$ and $\mathrm{A} 1$ induced by CD40 signaling in WEHI-231 cells are not sufficient for completely blocking BCR-mediated apoptosis in the absence of cell cycle progression.

\section{Expression of $\mathrm{p} 16^{\mathrm{INK} 4 \mathrm{a}}$ or p21 ${ }^{\text {cip1 }}$ partially inhibits CD40-mediated survival of WEHI-231 cells}

We asked whether other CDK inhibitors such as $\mathrm{p} 16^{\mathrm{INK} 4 \mathrm{a}}$ and p21 cip1 inhibit CD40-mediated survival, as is the case for $\mathrm{p} 27^{\mathrm{kip} 1}$. Infection with retrovirus expressing $\mathrm{p} 16^{\mathrm{INK} 4 \mathrm{a}}$ or p2 $1^{\text {cip } 1}$ induced cell cycle arrest in G1 in a manner dependent on virus titer (data not shown) in WEHI-231 cells. Expression of $\mathrm{p} 16^{\text {INK4a }}$ significantly increased the percentage of dead cells in WEHI-231 cells treated with anti-IgM and anti-CD40 antibodies (Figure 6), as is the case for expression of $\mathrm{p} 27^{\mathrm{kip} 1}$. Essentially, the same result was obtained when WEHI-231 cells were infected with cip1 virus (data not shown). These results indicated that CD40-mediated survival of WEHI-231 cells is partially blocked by expression of CDK inhibitors including $\mathrm{p} 16^{\mathrm{INK} 4 \mathrm{a}}, \mathrm{p} 21^{\mathrm{cip} 1}$ and $\mathrm{p} 27^{\mathrm{kip} 1}$.

\section{Discussion}

We demonstrate that BCR-ligated WEHI-231 cells are rescued by CD40 ligation only partially from apoptosis when cell cycle is arrested by retrovirus-mediated p2 $7^{\text {kip } 1}$ expression. Since both cell cycle arrest and reduction of CD40mediated survival of WEHI-231 are proportional to the titer of kip1-virus used for infection, it is likely that the reduction of CD40-mediated survival is due to cell cycle inhibition by p2 $7^{\text {kip1 }}$, but not its toxic effect if it carries any. Exclusion of the toxic effect of $\mathrm{p} 27^{\mathrm{kip} 1}$ is also supported by our finding that p2 $7^{\text {kip1 }}$ expression induces apoptosis only marginally in WEHI-231 cells, without anti-Ig treatment. Further, expression of $\mathrm{p} 16^{\mathrm{INK} 4 \mathrm{a}}$ or $\mathrm{p} 21^{\mathrm{cip} 1}$ also reduces CD40-mediated survival of WEHI-231 cells. Thus, CD40 appears to abrogate 


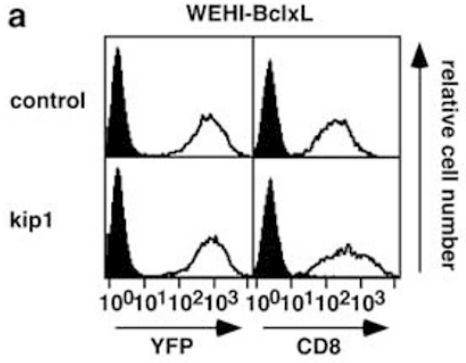

C
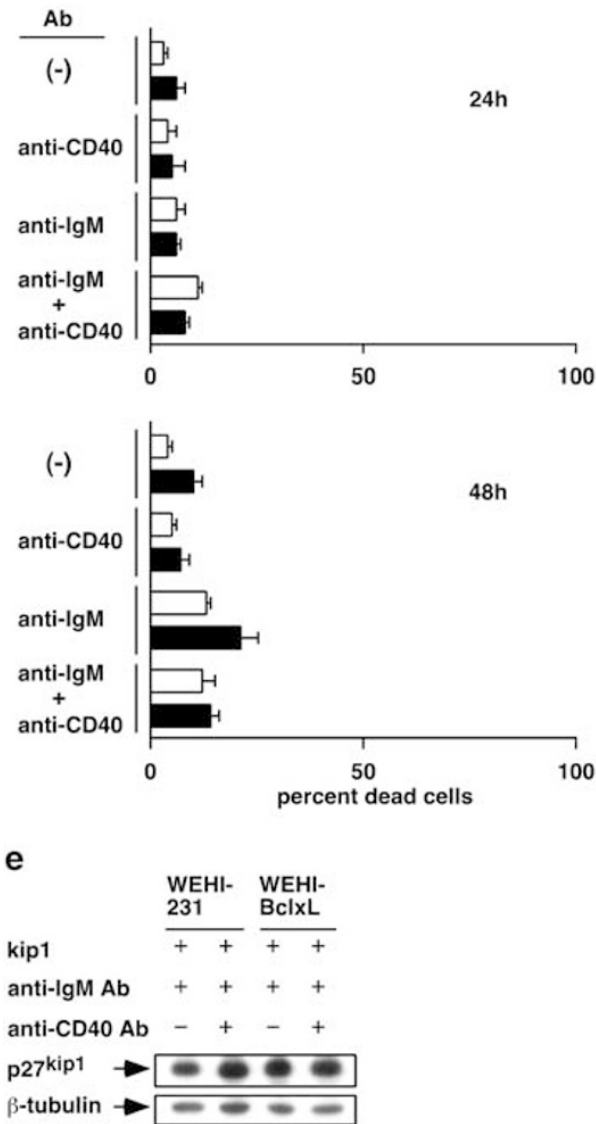

b

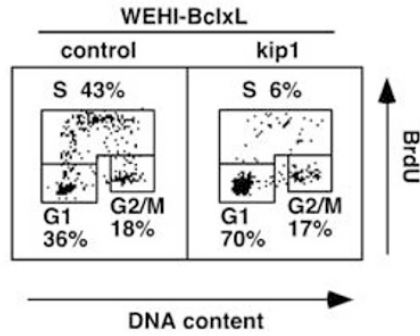

d

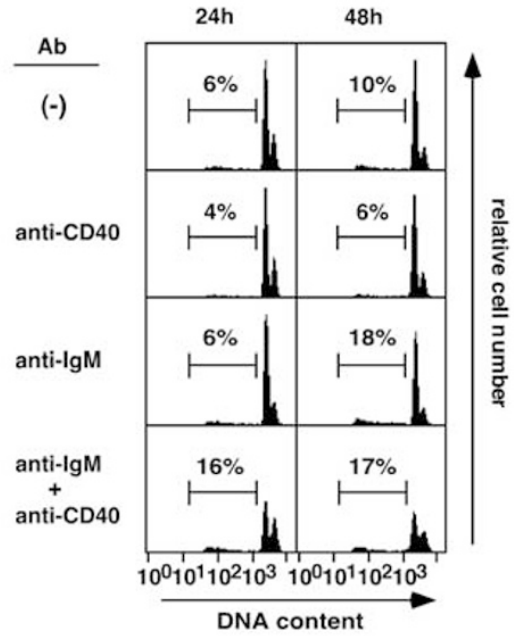

f

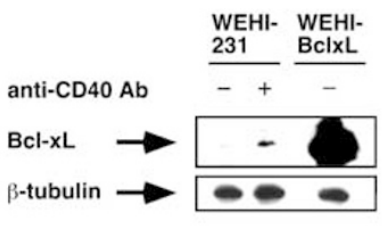

Figure 5 Overexpression of Bcl-xL blocks BCR-mediated apoptosis in p27 ${ }^{\text {kip } 1}$-expressing WEHI-231 cells. WEHI-231 cells were infected with the retrovirus expressing both Bcl-xL and YFP. The resulting WEHI-Bcl-xL cells were infected with retrovirus expressing both p2 $7^{\mathrm{kip} 1}$ and CD8 (kip1) or CD8 alone (control) for $4 \mathrm{~h}$. (a, b) Infection with kip1 virus induces cell cycle arrest in WEHI-Bcl-xL cells. Cells were cultured in medium for $24 \mathrm{~h}$. They were then analyzed for expression of YFP and CD8 by flow cytometry (a). Alternatively, cells were pulsed with BrdU, and cell cycle status was analyzed by flow cytometry (b). (c-e) Bcl-xL expression does not modulate p27 ${ }^{\text {kip1 }}$ expression, but blocks BCR-mediated apoptosis in WEHI-231 cells. Cells were cultured with $10 \mu \mathrm{g} / \mathrm{ml} \mathrm{F}\left(\mathrm{ab}^{\prime}\right)_{2}$ fragments of goat anti-mouse lgM Ab, $10 \mu \mathrm{g} / \mathrm{ml}$ anti-mouse CD40 mAb HM40-3, or both. After 24 or $48 \mathrm{~h}$, percentages of dead cells (c) and apoptotic cells (d) were measured by Trypan blue staining and flow cytometry, respectively. Percentages of dead cells are shown (c). The data represent mean \pm S.D. of triplicate cultures. Percentages of cells with hypodiploid nuclei characteristic for apoptosis are indicated (d). Representative data of three experiments are shown. Alternatively, cells were cultured for $24 \mathrm{~h}$, and expression of $\mathrm{p} 27^{\mathrm{kip} 1}$ in cell lysates was analyzed by Western blotting using anti-p2 $7^{\mathrm{kip} 1} \mathrm{mAb}(\mathbf{e})$. The same blot was reprobed with anti- $\beta$-tubulin mAb to ensure equal loading. (f) The level of Bcl-xL in WEHI-BclxL cells is much higher than that induced by CD40 ligation in WEHI-231 cells. Cells were cultured with or without anti-CD40 Ab for $6 \mathrm{~h}$, and expression of Bcl-xL in cell lysates was analyzed by Western blotting using anti-Bcl-xL Ab. The same blot was reprobed with anti- $\beta$-tubulin mAb to ensure equal loading. Representative data of three experiments are shown

BCR-mediated apoptosis only partially when cell cycle is arrested through expression of CDK inhibitors. Expression of $\mathrm{Bcl}-\mathrm{xL}$ or $\mathrm{A} 1$ induces the survival of BCR-ligated $\mathrm{B}$ cells without cell cycling. ${ }^{15,17}$ This indicates that cell cycle progression is not required for survival induced by $\mathrm{BCl}-\mathrm{xL}$ or $A 1$, and suggests that cell cycle arrest does not block the antiapoptotic activity of these molecules. Moreover, p2 $7^{\mathrm{kip} 1}$ expression does not modulate the levels of $\mathrm{Bcl}-\mathrm{xL}$ and $\mathrm{A} 1$. Thus, p27 $7^{\text {kip1 }}$ expression reduces CD40-mediated survival without perturbing the expression or function of $\mathrm{Bcl}-\mathrm{xL}$ or $\mathrm{A} 1$, indicating that CD40-mediated expression of these molecules is not sufficient for fully protecting B cells from apoptosis. In contrast, overexpression of $\mathrm{Bcl}-\mathrm{xL}$ induces the survival of BCR-ligated WEHI-231 cells even in the presence of cell cycle 

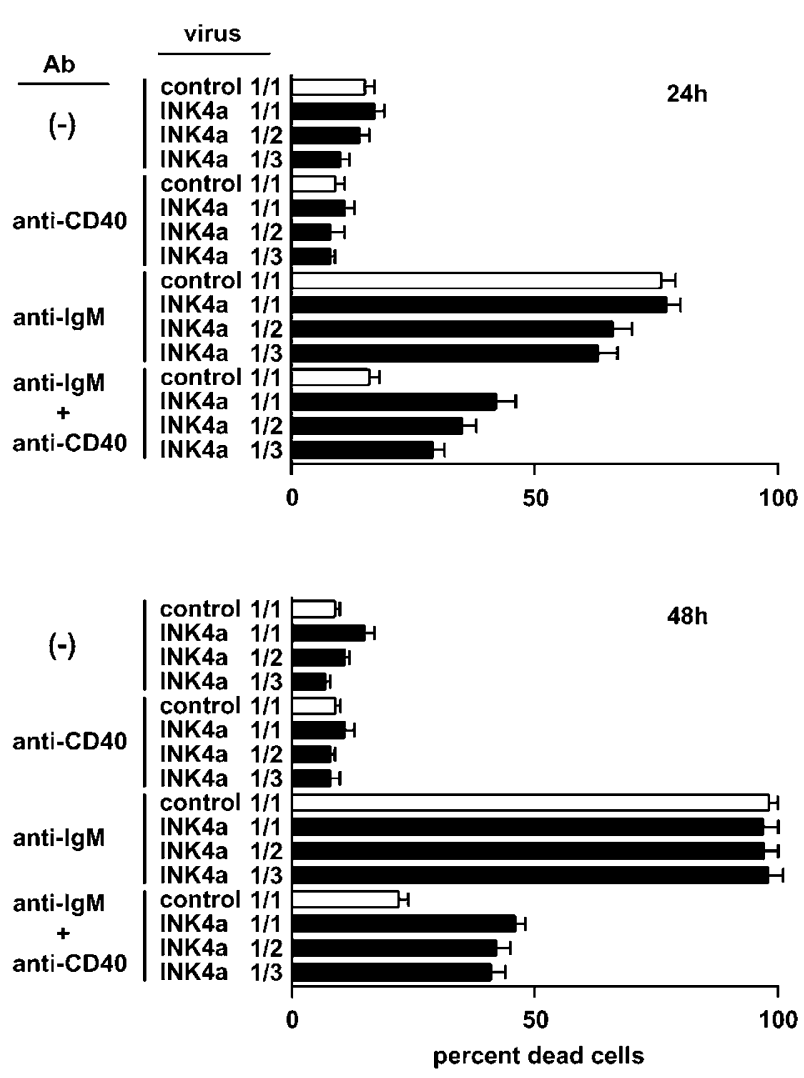

Figure 6 Expression of $p 16^{\text {INK4a }}$ partially blocks CD40-mediated survival of WEHI-231 cells. The supernatants containing retrovirus expressing both $11^{\text {INK4a }}$ and GFP (INK4a) or GFP alone (control) were either undiluted (1/1) or diluted by two-fold (1/2) or three-fold (1/3), and were incubated with WEHI-231 cells. Cells were then cultured with $10 \mu \mathrm{g} / \mathrm{ml}$ of $\mathrm{F}\left(\mathrm{ab}^{\prime}\right)_{2}$ fragments of goat anti-mouse IgM Ab, $10 \mu \mathrm{g} / \mathrm{ml}$ anti-mouse CD40 mAb HM40-3 or both for $24 \mathrm{~h}$ (upper panel) or $48 \mathrm{~h}$ (lower panel). Viability of the cells was assessed by Trypan blue staining, and percentages of dead cells were calculated. The data represent mean \pm S.D. of triplicate cultures. Representative data of three experiments are shown

arrest, suggesting that high-level expression of antiapoptotic members of the Bcl-2 family blocks apoptosis even in the presence of cell cycle arrest. Thus, expression of these antiapoptotic members of Bcl-2 family by CD40 ligation is not sufficient, but requires coexistence of cell cycle progression for full survival of BCR-ligated B cells. Cell cycle progression appears to be involved in antiapoptotic activity of CD40 signaling.

When B-cell lines such as WEHI-231 undergo BCR ligationinduced apoptosis, cell cycle is arrested prior to apoptosis. ${ }^{21-}$ ${ }^{24}$ Since restoration of cell cycle progression is involved in CD40-mediated abrogation of apoptosis in BCR-ligated WEHI-231 cells, cell cycle arrest induced by BCR ligation may be involved in BCR-mediated apoptosis in these cells. Involvement of cell cycle arrest in BCR-mediated apoptosis was previously suggested by Sonnenshine and colleagues. They reported that WEHI-231 transfectants constitutively expressing c-Myc, essential for cell proliferation, fail to undergo apoptosis upon BCR ligation. ${ }^{25}$ They further reported that treatment with anti-sense oligonucleotides for cip1 and kip1 reduces BCR-mediated apoptosis. ${ }^{26}$ Based on these findings, they suggested that reduction of c-Myc causes cell cycle arrest by increasing the levels of CDK inhibitors, thereby inducing apoptosis in BCR-ligated WEHI-231 cells. However, later studies using inducible activation of c-Myc demonstrated that c-Myc rather enhances apoptosis, ${ }^{27}$ and suggested that Sonnenshine's observation may be due to apoptosis-resistant variants obtained during establishment of stable transfectants. They also failed to rule out the possibility that antisense oligonucleotides to kip1 and cip1 induce the survival of WEHI231 cells by their nonspecific effects as oligonucleotides, such as activation of TLR-9, transmitting a survival signal, ${ }^{28}$ and of dsRNA-activated kinase. ${ }^{29}$ Recently, Banerji et al. ${ }^{30}$ demonstrated that expression of $\mathrm{p} 27^{\mathrm{kip} 1}$ induces both cell cycle arrest and apoptosis in WEHI-231 cells. This observation indicates that $\mathrm{p} 27^{\mathrm{kip} 1}$ can induce apoptosis, but does not show whether BCR-mediated apoptosis requires p2 $7^{\mathrm{kip} 1}$ and/or cell cycle arrest. Thus, whether cell cycle arrest induced by BCR ligation is involved in BCR-mediated apoptosis is to be elucidated using appropriate tools.

Cytokines such as IL-3 and IL-7 induce survival as well as proliferation. ${ }^{31,32}$ Although these cytokines activate signaling pathways distinct from that through CD40, these cytokines induce the expression of antiapoptotic members of the $\mathrm{Bcl}-2$ family, as is the case for CD40 ligation. ${ }^{12,14,15,17}$ IL-3 induces expression of $\mathrm{BCl}-\mathrm{xL},{ }^{32}$ and its overexpression reverses the apoptosis induced by IL-3 deprivation in BaF3 cells without restoring cell cycling. ${ }^{33} \mathrm{IL}-7$ induces the expression of $\mathrm{Bcl}-2,{ }^{31}$ and its constitutive expression restores defects in the generation of various hematopoietic cells in IL-7-deficient mice. $^{34,35}$ These observations suggest that expression of antiapoptotic members of the Bcl-2 family is involved in survival induced by cytokines. However, these cytokines reduce the $\mathrm{p} 27^{\mathrm{kip} 1}$ level and increase the levels of CDKs, ${ }^{36,37}$ as is the case for CD40 signaling. Therefore, it could be possible that cytokine-induced full survival requires cell cycle progression through regulation of CDKs and their inhibitors.

It is already established that cell cycle progression regulates survival when cell cycle is arrested by checkpoint activation. ${ }^{38,39}$ For instance, ionizing irradiation induces DNA damage, which activates DNA damage checkpoint, thereby causing cell cycle arrest. ${ }^{40}$ The arrest allows the cells to repair DNA damage before proceeding cell cycle progression. Abrogation of checkpoint causes immature cell cycle entry, resulting in mitotic catastrophe and cell death. ${ }^{41}$ Thus, cell cycle progression promotes cell death when cell cycle checkpoints are activated. However, cell cycle progression enhances survival but not apoptosis when CD40 signaling regulates $B$-cell apoptosis. Moreover, cell cycle checkpoints do not appear to be activated when $B$ cells undergo spontaneous or BCR-mediated apoptosis. Cell cycle progression by CD40 signaling thus regulates B-cell apoptosis independently of checkpoint activation. Checkpoint-independent regulation of apoptosis by cell cycle progression occurs in other cell types. For instance, expression of the CDK inhibitors $\mathrm{p} 16^{\mathrm{INK} 4 \mathrm{a}}$ and $\mathrm{p} 21^{\mathrm{cip} 1}$ enhances survival in the myoblast C2C12 upon differentiation. ${ }^{42}$ In contrast, expression of CDK inhibitors induces apoptosis in various cell types such as HeLa. ${ }^{43}$ In serum-deprived HUVEC, caspasedependent degradation of CDK inhibitors promotes cell cycling and retards apoptosis. ${ }^{44}$ In these examples, check- 
point does not appear to be activated, but cell cycle inhibitors regulate apoptosis. Interestingly, cell cycle progression appears to enhance apoptosis in $\mathrm{C} 2 \mathrm{C} 12$ cells and serumdeprived HUVEC, but is involved in B-cell survival by a signal through CD40, and is antiapoptotic in cells such as HeLa. Cell cycle progression thus regulates apoptosis in various cell types even in the absence of cell cycle checkpoint activation, but how it regulates appears to depend on the cellular context, probably including cell types and differentiation status. Since both cell cycle control and apoptosis are crucial events in cells, elucidation of crosstalk between them is likely to be crucial for understanding the regulations of both cell proliferation and apoptosis, and also actions of survival signals such as that through CD40 and cytokines.

\section{Materials and Methods}

\section{Cell culture}

The mouse B-lymphoma line WEHI-231 and its Bcl-2 transfectant WEHI$\mathrm{Bcl} 2^{18}$ were cultured in RPMI 1640 medium supplemented with $10 \% \mathrm{FCS}$, $50 \mu \mathrm{M}$ 2-mercaptoethanol and $2 \mathrm{mM}$ L-glutamine in the presence or absence of $10 \mu \mathrm{g} / \mathrm{ml} \mathrm{F}\left(\mathrm{ab}^{\prime}\right)_{2}$ fragments of goat anti-mouse IgM Ab (ICN Pharmaceuticals, Aurora, $\mathrm{OH}, \mathrm{USA})$ and $10 \mu \mathrm{g} / \mathrm{ml}$ anti-mouse CD40 monoclonal antibody (mAb) HM40-3 (kindly provided by Dr. Yagita, Juntendo University, Tokyo, Japan).

\section{Plasmids}

The retroviral vector pMx-IRES-CD8 and pMx-IRES-YFP were constructed by replacing the GFP CDNA in the pMx-IRES-GFP (kindly provided by Drs. Kitamura and Miyajima, University of Tokyo, Tokyo, Japan $)^{45}$ by a Notl-Sall fragment encoding mouse CD $8^{46}$ and a Notl-Sall fragment encoding YFP, respectively. The EcoRI-Xhol fragment containing kip1 $\mathrm{CDNA}$ was isolated from $\mathrm{pBS}-\mathrm{Kip1}^{20}$ and inserted into the EcoRIXhol site of pMx-IRES-GFP and pMx-IRES-CD8, resulting in pMx-Kip1IRES-GFP and pMx-Kip1-IRES-CD8, respectively (Figure 1). The BamHI fragment containing INK4a CDNA was isolated from pCMV-FLp16 (kindly provided by Dr. Harlow, MGH Cancer Center, Charlestown, USA), ${ }^{47}$ inserted into the BamHI site of pUC19, and then recovered as an EcoRISall fragment. pMx-INK4a-IRES-GFP was constructed by inserting this EcoRI-Sall fragment into the EcoRI-Xhol site of pMx-IRES-GFP. The cip1 cDNA was obtained by RT-PCR using WEHI-231 cells with a set of primers: 5'-AGAATTCATGTCCAATCCTGGTGAT-3' and 5'-ACTCGAGTCAGGGTTTTCTCTTGCA-3'. The EcoRl-Xhol fragment containing cip1 CDNA was inserted into the ECORI-Xhol site of pMx-IRES-GFP, resulting in the retrovirus vector pMxCip1-IRES-GFP. A pair of synthetic oligonucleotides (5'-AATTCAACTCGAGAAGCGGCCGGCG-3' and 5'TCGACGCGGCCGCTTCTCGAGTTG-3') was annealed and ligated with the EcoRI-Xhol-opened pMx-IRES-YFP. The resulting plasmid was digested with EcoRI and inserted with the DNA fragment containing the $H A$ tag generated by annealing a set of synthetic oligonucleotides $\left(5^{\prime}\right.$ AATTAAGAAAATGTATCCCTATGACGTGCCCGACTATGCGG- $3^{\prime}$ and 5'AATTCCGCATAGTCGGGCACGTCATAGGGATACATTTTCTT-3'). The resulting plasmid was designated as pMx-HA-IRES-YFP. The Bcl-xL $\mathrm{CDNA}^{48}$ was obtained by RT-PCR from WEHI-231 cells using a set of primers: $\quad 5^{\prime}$-AACTCGAGAATGTCTCAGAGCAACCGG-3' and $5^{\prime}$ AAGCGGCCGCTCACTTCCGACTGAAGAG-3'. The Xhol-Notl fragment containing Bcl-xL cDNA was inserted into the Xhol-Notl site of pMx-HA-
IRES-YFP, resulting in the retrovirus vector $p M x B c l-x L-I R E S-Y F P$ encoding the retrovirus expressing both $\mathrm{Bcl}-\mathrm{xL}$ and YFP.

\section{Retrovirus infection}

The retrovirus packaging cell line Plat-E (kindly provided by Dr. Kitamura $^{49}$ was maintained in Dulbecco's Modified Eagle Medium supplemented with $10 \% \mathrm{FCS}$ and $2 \mathrm{mM} \mathrm{L-glutamine.} \mathrm{Plat-E} \mathrm{cells}\left(1 \times 10^{6}\right)$ were seeded into $60 \mathrm{~mm}$ dishes. After $24 \mathrm{~h}$, cells were transfected retroviral vectors using Fugene6 (Roche Diagnostics Corp., Indianapolis, USA). Cells were cultured for $48 \mathrm{~h}$, and $1.5 \mathrm{ml}$ of the culture supernatant was incubated with $5 \times 10^{5}$ WEHI-231 for $4 \mathrm{~h}$. After $24 \mathrm{~h}$, expression of GFP and YFP was analyzed by flow cytometry using a FACSCalibur (BD Biosciences, San Jose, USA). Alternatively, cells were stained with biotinylated anti-CD8 mAb TIB-105 and phycoerythrin (PE)-conjugated streptavidine (DAKO, Glostrup, Denmark), and analyzed by flow cytometry.

\section{Western blot analysis}

Cells were washed with PBS, and lysed in SDS-PAGE sample buffer. Proteins were subjected to SDS-PAGE on a 10 or $15 \%$ acrylamide gel under reducing conditions, and transferred to PVDF membranes (Amersham Biosciences, NJ, USA). Membranes were incubated with mouse anti-p2 $7^{\mathrm{kip} 1} \mathrm{mAb}$ (BD Biosciences) or mouse anti- $\beta$-tubulin $\mathrm{mAb}$ (Seikagaku Co., Tokyo, Japan), followed by incubation with peroxidaseconjugated sheep anti-mouse $\lg \mathrm{Ab}$ (Amersham Biosciences). Alternatively, membranes were reacted by goat anti-A1 Ab (Santa Cruz Biotechnology, CA, USA) or rabbit anti-Bcl-xL Ab (Santa Cruz Biotechnology), followed by incubation with peroxidase-conjugated donkey anti-goat IgG Ab (Santa Cruz Biotechnology) or peroxidaseconjugated goat anti-rabbit Ig Ab (New England Biolabs Inc., MA, USA), respectively. Proteins were then visualized by ECL system (Amersham Biosciences).

\section{Cell cycle analysis}

Cells were pulsed with $20 \mu \mathrm{M}$ of 5-bromo-2'-deoxyuridine (BrdU) at $37^{\circ} \mathrm{C}$ for the last $20 \mathrm{~min}$ of culture, and then fixed with $70 \%$ ethanol overnight at $-20^{\circ} \mathrm{C}$. Cells were then stained with fluorescein isothiocyanate (FITC)labeled anti-BrdU Ab (BD Biosciences) and $5 \mu \mathrm{g} / \mathrm{ml}$ of propidium iodide $(\mathrm{PI})$, and analyzed by flow cytometry using a FACSCalibur (BD Biosciences).

\section{Assay of apoptotic cells}

Cells were fixed in $70 \%$ ethanol overnight at $-20^{\circ} \mathrm{C}$, washed with PBS, and incubated in $1 \mathrm{ml}$ PBS containing $50 \mu \mathrm{g} / \mathrm{ml}$ RNase A for $30 \mathrm{~min}$ at $37^{\circ} \mathrm{C}$. PI was added to a final concentration of $50 \mu \mathrm{g} / \mathrm{ml}$, and cells were analyzed by flow cytometry using a FACSCalibur (BD Biosciences).

\section{Acknowledgements}

We thank Drs. Y Kitamura, A Miyajima, Y Terada (Tokyo Medical and Dental University), E Harlow and $\mathrm{H}$ Yagita for reagents and Mr. K Mizuno for technical help. This work was supported by grants from the Ministry of Education, Culture, Sport, Science and Technology, Ministry of Health, Labor and Welfare of Japan. 


\section{References}

1. Banchereau J, Bazon F, Blanchard D, Briere F, Galizzi JP, van Kooten C, Liu YJ, Rousset F and Saeland S (1994) The CD40 antigen and its ligand. Annu. Rev. Immunol. 12: 881-922

2. van Kooten $C$ and Banchereau J (1997) Functions of CD40 on B cells, dendritic cells and other cells. Curr. Opin. Immunol. 9: 330-337

3. Tsubata T, Wu J and Honjo T (1993) B-cell apoptosis induced by antigen receptor crosslinking is blocked by a T-cell signal through CD40. Nature 364 : 645-648

4. Parry SL, Holman MJ, Hasbold J, Klaus GG and Holman M (1994) Plasticimmobilized anti- $\mu$ or anti- $\delta$ antibodies induce apoptosis in mature murine $\mathrm{B}$ Iymphocytes. Eur. J. Immunol. 24: 974-979

5. Parry SL, Hasbold J, Holman M and Klaus GG (1994) Hypercross-linking surface $\operatorname{lgM}$ or $\operatorname{lgD}$ receptors on mature $B$ cells induces apoptosis that is reversed by costimulation with IL-4 and anti-CD40. J. Immunol. 152: 2821-2829

6. Tsubata $T$ (2001) Molecular mechanisms for apoptosis induced by signaling through the B cell antigen receptor. Int. Rev. Immunol. 20: 791-803

7. Budihardjo I, Oliver H, Lutter M, Luo X and Wang X (1999) Biochemical pathways of caspase activation during apoptosis. Annu. Rev. Cell Dev. Biol. 15: 269-290

8. Green DR (2000) Apoptotic pathways: paper wraps stone blunts scissors. Cell 102: $1-4$

9. Roy S and Nicholson DW (2000) Cross-talk in cell death signaling. J. Exp. Med. 192: F21-F25

10. Mackus WJ, Lens SM, Medema RH, Kwakkenbos MJ, Evers LM, Oers MH, Lier RA and Eldering $E$ (2002) Prevention of $B$ cell antigen receptor-induced apoptosis by ligation of $\mathrm{CD} 40$ occurs downstream of cell cycle regulation. Int. Immunol. 14: 973-982

11. Ruiz-Vela A, Gonzalez de Buitrago $G$ and Martinez AC (1999) Implication of calpain in caspase activation during $B$ cell clonal deletion. EMBO J. 18: 4988-4998

12. Choi MS, Boise LH, Gottschalk AR, Quintans J, Thompson CB and Klaus GG (1995) The role of bcl- $\mathrm{X}_{\mathrm{L}}$ in CD40-mediated rescue from anti- $\mu$ induced apoptosis in WEHI-231 B lymphoma cells. Eur. J. Immunol. 25: 1352-1357

13. Fang W, Rivard JJ, Ganser JA, LeBien TW, Nath KA, Mueller DL and Behrens TW (1995) Bcl-xL rescues WEHI 231 B lymphocytes from oxidant-mediated death following diverse apoptotic stimuli. J. Immunol. 155: 66-75

14. Wang Z, Karras JG, Howard RG and Rothstein TL (1995) Induction of $b c l-x$ by CD40 engagement rescues slg-induced apoptosis in murine B cells. J. Immunol. 155: 3722-3725

15. Ishida T, Kobayashi N, Tojo T, Ishida S, Yamamoto T and Inoue J (1995) CD40 signaling-mediated induction of $\mathrm{Bcl}-\mathrm{x}_{\mathrm{L}}, \mathrm{Cdk} 4$, and $\mathrm{Cdk6}$. Implication of their cooperation in selective B cell growth. J. Immunol. 155: 5527-5535

16. Merino R, Grillot DA, Simonian PL, Muthukkumar S, Fanslow WC, Bondada $S$ and Nunez $G$ (1995) Modulation of anti-IgM-induced B cell apoptosis by Bcl- $\mathrm{X}_{\mathrm{L}}$ and CD40 in WEHI-231 cells. Dissociation from cell cycle arrest and dependence on the avidity of the antibody-IgM receptor interaction. J. Immunol. 155: $3830-3838$

17. Kuss AW, Knodel M, Berberich-Siebelt F, Lindemann D, Schimpl A and Berberich I (1999) A1 expression is stimulated by CD40 in B cells and rescues WEHI 231 cells from anti-IgM-induced cell death. Eur. J. Immunol. 29: 3077-3088

18. Yoshida $T$, Higuchi $T$, Hagiyama $H$, Strasser $A$, Nishioka $K$ and Tsubata $T$ (2000) Rapid B cell apoptosis induced by antigen receptor ligation does not require Fas (CD95/APO-1), the adaptor protein FADD/MORT1 or CrmAsensitive caspases but is defective in both MRL-+/+ and MRL-/pr//pr mice. Int. Immunol. 12: 517-526

19. Solvason N, Wu WW, Kabra N, Wu X, Lees E and Howard MC (1996) Induction of cell cycle regulatory proteins in anti-immunoglobulin-stimulated mature $B$ lymphocytes. J. Exp. Med. 184: 407-417

20. Han H, Nomura T, Honjo T and Tsubata T (1996) Differential modulation of cyclin-dependent kinase inhibitor $p 27^{\text {Kip1 }}$ by negative signaling via the antigen receptor of $B$ cells and positive signaling via CD40. Eur. J. Immunol. 26: 2425-2432

21. Scott DW, Tuttle J, Livnat D, Haynes W, Cogswell JP and Keng P (1985) Lymphoma models for B-cell activation and tolerance. II. Growth inhibition by anti- $\mu$ of WEHI-231 and the selection and properties of resistant mutants. Cell. Immunol. 93: 124-131

22. Scott DW, Livnat D, Pennell CA and Keng P (1986) Lymphoma models for B cell activation and tolerance. III. Cell cycle dependence for negative signalling of WEHI-231 B lymphoma cells by anti- $\mu$. J. Exp. Med. 164: 156-164

23. Benhamou LE, Cazenave PA and Sarthou P (1990) Anti-immunoglobulins induce death by apoptosis in WEHI-231 B lymphoma cells. Eur. J. Immunol. 20: $1405-1407$

24. Hasbold J and Klaus GG (1990) Anti-immunoglobulin antibodies induce apoptosis in immature B cell lymphomas. Eur. J. Immunol. 20: 1685-1690

25. Wu M, Yang W, Bellas RE, Schauer SL, FitzGerald MJ, Lee $\mathrm{H}$ and Sonenshein GE (1997) c-myc promotes survival of WEHI 231 B lymphoma cells from apoptosis. Curr. Top. Microbiol. Immunol. 224: 91-101

26. Wu M, Bellas RE, Shen J and Sonenshein GE (1998) Roles of the tumor suppressor p53 and the cyclin-dependent kinase inhibitor ${ }^{\text {Cip } 1 / \text { Waf1 }}$ in receptormediated apoptosis of WEHI 231 B lymphoma cells. J. Exp. Med. 187: 16711679

27. Hagiyama H, Adachi T, Yoshida T, Nomura T, Miyasaka N, Honjo $T$ and Tsubata T (1999) Signaling through the antigen receptor of B lymphocytes activates a p53-independent pathway of c-Myc-induced apoptosis. Oncogene 18: $4091-4098$

28. Hemmi H, Takeuchi O, Kawai T, Kaisho T, Sato S, Sanjo H, Matsumoto M, Hoshino K, Wagner H, Takeda K and Akira S (2000) A Toll-like receptor recognizes bacterial DNA. Nature 408: 740-745

29. Bevilacqua PC and Cech TR (1996) Minor-groove recognition of doublestranded RNA by the double-stranded RNA-binding domain from the RNAactivated protein kinase PKR. Biochemistry 35: 9983-9994

30. Banerji L, Glassford J, Lea NC, Thomas NS, Klaus GG and Lam EW (2001) $\mathrm{BCR}$ signals target $\mathrm{p} 27^{\mathrm{Kip} 1}$ and cyclin $\mathrm{D} 2$ via the $\mathrm{PI} 3-\mathrm{K}$ signalling pathway to mediate cell cycle arrest and apoptosis of WEHI 231 B cells. Oncogene 20: 7352-7367

31. von Freeden-Jeffry U, Solvason N, Howard M and Murray R (1997) The earliest T lineage-committed cells depend on IL-7 for Bcl-2 expression and normal cell cycle progression. Immunity 7: 147-154

32. Kieslinger M, Woldman I, Moriggl R, Hofmann J, Marine JC, Ihle JN, Beug H and Decker T (2000) Antiapoptotic activity of Stat5 required during terminal stages of myeloid differentiation. Genes Dev. 14: 232-244

33. Thomas J, Leverrier $Y$ and Marvel $\mathrm{J}$ (1998) $B c l-X$ is the major pleiotropic antiapoptotic gene activated by retroviral insertion mutagenesis in an IL-3 dependent bone marrow derived cell line. Oncogene 16: 1399-1408

34. Akashi K, Kondo M, von Freeden-Jeffry U, Murray R and Weissman IL (1997) $\mathrm{Bcl}-2$ rescues T lymphopoiesis in interleukin-7 receptor-deficient mice. Cell 89: 1033-1041

35. Maraskovsky E, O'Reilly LA, Teepe M, Corcoran LM, Peschon JJ and Strasser A (1997) Bcl-2 can rescue T lymphocyte development in interleukin-7 receptordeficient mice but not in mutant rag-1 $1^{-1-}$ mice. Cell 89: 1011-1019

36. Barata JT, Cardoso AA, Nadler LM and Boussiotis VA (2001) Interleukin-7 promotes survival and cell cycle progression of T-cell acute lymphoblastic leukemia cells by down-regulating the cyclin-dependent kinase inhibitor p2 $7^{\mathrm{kip} 1}$. Blood 98: 1524-153

37. Parada Y, Banerji L, Glassford J, Lea NC, Collado M, Rivas C, Lewis JL, Gordon MY, Thomas NS and Lam EW (2001) BCR-ABL and interleukin 3 promote haematopoietic cell proliferation and survival through modulation of cyclin D2 and p2 $7^{\text {Kip1 }}$ expression. J. Biol. Chem. 276: 23572-23580

38. Elledge SJ (1996) Cell cycle checkpoints: preventing an identity crisis. Science 274: 1664-1672

39. McDonald III ER and El-Deiry WS (2001) Checkpoint genes in cancer. Ann. Med. 33: 113-122

40. Weinert TA and Hartwell LH (1988) The RAD9 gene controls the cell cycle response to DNA damage in Saccharomyces cerevisiae. Science 241: $317-322$

41. Terada Y, Tatsuka M, Jinno S and Okayama $H$ (1995) Requirement for tyrosine phosphorylation of Cdk4 in G1 arrest induced by ultraviolet irradiation. Nature 376: 358-362

42. Wang J and Walsh K (1996) Resistance to apoptosis conferred by Cdk inhibitors during myocyte differentiation. Science 273: 359-361

43. Wang X, Gorospe M, Huang Y and Holbrook NJ (1997) p2 $7^{\text {kip } 1}$ overexpression causes apoptotic death of mammalian cells. Oncogene 15: 2991-2997 
44. Levkau B, Koyama H, Raines EW, Clurman BE, Herren B, Orth K, Roberts JM and Ross $\mathrm{R}$ (1998) Cleavage of p21 $1^{\mathrm{Cip} 1 / \mathrm{Waf} 1}$ and p27 $7^{\mathrm{Kip} 1}$ mediates apoptosis in endothelial cells through activation of Cdk2: role of a caspase cascade. Mol. Cell 1: 553-563

45. Misawa K, Nosaka T, Morita S, Kaneko A, Nakahata T, Asano S and Kitamura $\mathrm{T}(2000)$ A method to identify cDNAs based on localization of green fluorescent protein fusion products. Proc. Natl. Acad. Sci. USA 97: 3062-3066

46. Nakauchi H, Nolan GP, Hsu C, Huang HS, Kavathas P and Herzenberg LA (1985) Molecular cloning of Lyt-2, a membrane glycoprotein marking a subset of mouse T lymphocytes: molecular homology to its human counterpart, Leu-2/
T8, and to immunoglobulin variable regions. Proc. Natl. Acad. Sci. USA 82: $5126-5130$

47. Koh J, Enders GH, Dynlacht BD and Harlow E (1995) Tumour-derived p16 alleles encoding proteins defective in cell-cycle inhibition. Nature 375: 506-510

48. Gonzalez-Garcia M, Perez-Ballestero R, Ding L, Duan L, Boise LH, Thompson $C B$ and Nunez $G$ (1994) $b c l-x_{L}$ is the major $b c l-x$ mRNA form expressed during murine development and its product localizes to mitochondria. Development 120: 3033-3042

49. Morita S, Kojima T and Kitamura T (2000) Plat-E: an efficient and stable system for transient packaging of retroviruses. Gene Therapy 7: 1063-1066 